\title{
BARON MUNDY, M.D.
}

The death of Baron Jaromir Mundy, M.D., of Vienna, in the University of which he was formerly Professor of Military Hygiene, and an Honorary Member of our Association, will recall his memory to many of the older members, while to the majority he is almost unknown, even by name. He died on the 23rd of August, aged 72. Mundy, who was a convert to the non-restraint system, from what he had seen in the English asylums, wrote in the "Journal of Mental Science" (April, 1864) in its favour, while translating a paper by Ludwig Meyer defending Conollyism against Casimir.Pinel and others on the Continent, who termed it "The English Swindle." The article was headed "An Oasis in the Desert of German Restraint."* The first occasion on which he read a paper on his pet subject, "The Cottage System," before the Medico-Psychological Association, was at the Annual Meeting of 1863. After a residence of four years in England Mundy made, at the Annual Meeting (October, 186.4), a series of proposals as to whether the system of treatment in asylums was satisfactory, including the clinical instruction in mental science; and, further, whether the administrative form of control of asylums, both on the part of the Government and other Corporations, was defective. Here and in other instances the Baron showed his wide views of the general subject of asylum management and treatment. At the same time, he made many references to his personal history. He said that family circumstances had not permitted him till somewhat advanced in years to devote his life to psychological medicine, although he had from youth felt an irresistible attraction to it. After long and patient study of the theury and practice of the science he re peatedly visited many European asylums. The melancholy system under which thousands were swallowed up in asylums attracted him to Gheel as the only part of the world in which nearly 1,000 persons were allowed to live cheaply in free air and liberty in the midst of sane people and their families. Then he became an ardent advocate of non-sequestration and of family treatment through the non-restraint system. Some advance had been made in this direction, but still he maintained that "the present system does not answer satisfactorily to the exigencies of the social, medical, and economical science of our time." Everyone, the Baron said, "had now become accustomed to sneer at mad doctors." His object clearly was to open the way for the cottage system of treatment. By the cuttage system, he said, he understood that first carried out by Dr. Bucknill, and followed by good results, and also by Dr. Lockhart Robertson at Haywards Heath. In advocating the Gheel system of caring for the insane, he observed in a lecture, delivered in 1867:- "Here upwards of 1,000 lunatics live free, without restraint, among the ordinary inhabitants, reside with them, cultivate with them the fields and farms, resort with them to church and school, act as nurses for their children, and lead an ordinary, natural family existence, such as we are accustomed to value in our own homes."

A paper Baron Mundy read before the Annual Meeting of the Association (Oct., 1867) on the "Laws of Lunacy in Europe" was especially noteworthy, because, after thanking it for having elected him an Honorary Member, he announced that it was probably the last time he should address the Association "before his retirement trom this branch of science."

'The last time we had the pleasure of seeing the excellent subject of this sketch was at the Annual Meeting of our Asscciation in 1884. In discussing the President's (Dr. Rayner's) Address he said:- "In regard to the 'cottage' or 'family' system, France stood nearly where it did 20 years ago, although there was much talk there about 'family treatment,' and some attempt at it. Norway, Italy, and Sweden were as before; and he was sorry to say Austria was still behind, except

- It is a curious illustration of how a foreigner may mistake the practices and laws of principle of non-restraint to a legislative Act, whereby the phyrician who should the pose restraint upon the insane is rendered liable to prosecution, and is exposed to the loes of his appointment."(!) 
in Vienna. In Germany progress had been made. He called their attention to a report at the Copenhagen Congress relative to the system in question, which was working well on an estate costing about $\$ 30,000$, which was bought for a lunatic asylum, but where the insane were living in the different houses which had been built before the inhabitants left. These were central infirmaries, but the system was a separate one. The Baron, however, confessed he did not believe such a system could be carried out in England.

Baron Mundy ought to be gratefully remembered and honoured for having devoted at one period of his life so much time and thought to the care of the insane. If his views are not carried out in our country on a large scale, the importance of the segregation of the insane is recognized to a far larger extent than formerly, and the wisdom of the typical asylums of Alt Scherbitz in Germany and Kankakee in Illinois is acknowledged by an increasing number of asylum physicians and architects: We regret to add that the Baron died by his own hand.

\section{EXAMINATION FOR THE CERTIFICATE IN PSYCHOLOGICAL MEDICINE.}

The following Candidates were successful at the Examination held on the 19th July, 1894 :-

$$
\begin{aligned}
& \text { England. } \\
& \text { Examined at Bethlem. Hospital, London. } \\
& \text { Frederick, Herbert John. Robson, Francis White Hope. } \\
& \text { King, Frederick Truby. Sheen, Alfred Will. } \\
& \text { Scotland. } \\
& \text { Examined at the Royal Asylum, Edinburgh. } \\
& \begin{array}{ll}
\text { Begg, William. } & \text { Hall, Henry Baker. } \\
\text { Dawson, William Richard. } & \text { Middlemass, James. }
\end{array} \\
& \text { Farquharson, William Frederick. Martin, William Lewis. } \\
& \text { Examined at the Royal Asylum, Aberdeen. } \\
& \text { Anderson, Bruce Arnold. Gawn, Ernest King. } \\
& \text { Cowie, George. Scott, George Brebner. }
\end{aligned}
$$

The following were the written questions:-

1. Describe the physiognomy in the chief forms of Mental Disease.

2. What is meant by Imbecility? Distinguish Imbecility from (1) Idiocy, (2) Dementia, and (3) Stupor. What legal formalities are necessary for placing an Imbecile under care?

3. Describe the mental character of Epilepsy, and the excitement succeeding seizures.

4. Describe $(a)$ the general and $(b)$ the medicinal treatment you would adopt for (1) Acute and (2) Chronic Alcoholic Insanity.

5. Describe the psychosis known as "Katatonia ;" discuss the views now held as to its being regarded as a separate morbid entity.

6. Describe a case of Puerperal Melancholia; give treatment and prognosis.

The next Examination will be held in December, 1894. Due notice of the date will be given in the "Lancet" and the "British Medical Journal."

WINNER OF THE BRONZE MEDAंL AND PRIZE OF TEN GUINEAS.

Cecil Fowler Beadles, M.R.C.S., L.R.C.P., London, Assistant Medical Officer, London County Asylum, Colney Hatch.

A Special Prize of Five Guineas was awarded to John Turner, M.B., C.M., Aberdeen, Assistant Medical Officer, Essex County Asylum, Brentwood, for the excellence of his essay.

There was no entry for the Gaskell Prize. 